\title{
THE DEVELOPMENT OF MEMBERS' ATTITUDES TOWARD THEIR UNIONS: SWEDEN AND CANADA
}

\author{
SAROSH KURUVILLA, DANIEL G. GALLAGHER, and KURT WETZEL*
}

\begin{abstract}
This study examines two widely researched attitudes of union members-satisfaction with and commitment to their union-using 1987-88 data on 1,675 union members in professional occupations in Sweden and 476 blue- and white-collar union members in Canada. The authors find, first, that union commitment and union satisfaction are theoretically and empirically different constructs. Second, tests of a theoretical model of union attitude formation indicate that different (though overlapping) sets of factors influence union commitment and union satisfaction. One finding is that activities and processes that provide members with greater information about the union, such as new member orientation programs, newsletters sent to members' homes, and participation in union activities, effectively promote union commitment, but not union satisfaction. The results are very similar across the two samples, suggesting that they have cross-cultural generalizability.
\end{abstract}

$\mathbf{I}^{\mathrm{N}}$ NDUSTRIAL relations research on union attitudes - that is, attitudes of workers toward unions-has typically focused on the extent to which the union attitudes of unorganized workers or union members influence union-related behavior, such as voting in certification elections, participating in union activities, and voting in decertification elections. A few studies

* Sarosh Kuruvilla is Assistant Professor, New York State School of Industrial and Labor Relations, Cornell University; Daniel G. Gallagher is Professor, College of Business, James Madison University; and Kurt Wetzel is Professor, College of Commerce, University of Saskatchewan. The authors thank Jack Fiorito, Paul Jarley, John Burton, Harry Katz, Chris Erickson, Barry Gerhart, Julian Barling, and Kevin Kelloway for helpful comments, and Jan Bröms and Anders Leion for their assistance in data collection. Partial funding for this project was provided by Grant No. 88288 from Arbetsmiljöfonden, Stockholm, to Sarosh Kuruvilla.

More details on the data, and computer programs used to generate the results in this paper, are available from Sarosh Kuruvilla at 156 Ives Hall, Cornell University, Ithaca, NY 14853-3901. have examined union attitude constructs as dependent variables, and have focused on the correlates of members' union commitment and union satisfaction. The psychological literature, on the other hand, has generally concentrated more on the measurement and factor structure of attitude constructs such as union commitment.

Despite the considerable interest in union attitudes, the industrial relations and psychological literatures have paid little attention to how union attitudes are formed. That question is of considerable significance to unions. For example, the report of the AFL-CIO Committee on the Evolution of Work (1985) suggested the need for increased commitment and activism by members to counteract the decline in union organizing in the previous decade. In particular, the Committee's new one-on-one organizing strategy was predicated on substantial member commitment and participation, and was designed to 
build positive worker attitudes toward unions at a local level. It therefore is important for unions to understand the factors that influence the formation of attitudes toward unions, both toward unionism in general and toward their own local or national union.

Unfortunately, several difficulties limit our ability to study union attitude formation from a policy perspective. First, the literature is characterized by inconsistent definitions of variables and numerous variations in the items used to measure union attitudes and in the labels used to identify them, since each researcher tends to use his or her own tailor-made attitudinal measure (Strauss and Gargano 1987). Second, theoretical frameworks supporting the selection of variables that relate to union attitudes are generally absent from the literature. Consequently, model building has been ad hoc and fragmented. A survey of the literature reveals, for example, a strikingly similar list of determinants for both union commitment and union satisfaction, suggesting that the two attitudes are similar, although each is usually treated as a distinct construct.

Conceptually and empirically clear constructs are necessary if research on members' attitudes toward unions is to move forward. In this study we examine the nature of the distinction between union satisfaction and union commitment and attempt to identify variables associated with these two constructs. Using crosssectional data collected in 1987 from samples of union members in Sweden and Canada, we assess the empirical distinction between union commitment and union satisfaction using the confirmatory factor analysis techniques of LISREL VII. We then estimate a model of union attitude formation, in order to identify variables that influence union commitment and union satisfaction. Use of the model permits comparisons of the factors affecting union satisfaction and union commitment within each country and also allows us to evaluate how similar the findings are across the two countries.

\section{Union Commitment and Union Satisfaction Literature}

Although union commitment and union satisfaction are both union-related attitudes, conceptually the two constructs have not been well distinguished. The definition of union commitment has been largely based on definitions of organizational commitment. Mowday et al. (1982: 27) noted that "commitment can be characterized by three factors, a) a strong belief in and acceptance of the organizations goals and values, b) a willingness to exert considerable effort on behalf of the organization, and c) a strong desire to maintain membership in the organization." Gordon et al. (1980) adopted the Mowday et al. definition, but further suggested that union commitment is characterized by a belief in unions, loyalty to the union, responsibility to the union, and willingness to work on behalf of the union.

Conceptualization of union satisfaction has been based on Locke's (1976:1299) definition of job satisfaction, "a pleasurable and positive emotional state resulting from the appraisal of one's job or job experiences, and ... a function of the perceived relationship between what one wants from one's job and what one perceives it as offering." Fiorito et al. (1988) adopted Locke's definition and suggested that union satisfaction is a function of the discrepancy between member expectations and perceptions of union performance on a number of job and union-related facets such as "bread and butter issues," internal relations between leaders and rank-and-file members, and improvements in the quality of working life.

We draw distinctions between union commitment and union satisfaction based on the distinction between organizational commitment and job satisfaction suggested by Mowday et al. (1982). Accordingly, union commitment is more global than union satisfaction, reflecting a general identification with the union and its goals and values. Union commitment is likely to develop slowly and consistently, and to be more stable over time than 
union satisfaction. In Mowday et al.'s (1982:28) terms, "Day to day events in the workplace may affect an employee's level of satisfaction, but such transitory events should not cause the employee to reevaluate seriously his or her attachment to the organization."

Union satisfaction, on the other hand, is more evaluative in nature than union commitment, and reflects immediate reactions to union performance on specific and tangible aspects of the work environment. Union satisfaction, therefore, is likely to be less stable over time than union commitment.

The primary distinction between the two attitudes is that union commitment reflects an identification with the union that is developed over a relatively long period, whereas union satisfaction is a more evaluative short-term phenomenon. A practical distinction between the two is illustrated by Klandermans' (1989) study of Dutch workers, which found that low union commitment is a stronger predictor of an employee's decision to leave the union than is low union satisfaction.

Despite the conceptual distinction noted above, however, an examination of the previous literature raises the possibility that these two constructs may not be empirically distinct. The correlations between the two measures are typically high (for example, .58 between measures of union loyalty and union satisfaction reported by Gordon et al. 1980). A number of researchers (for example, Fullagar and Barling 1987; Gallagher and Clark 1989; Fiorito et al. 1988) report strikingly similar sets of determinants for the two attitudes. Personal characteristics such as age, tenure, education, gender, and race, participation in union activity, general attitudes toward unions, and job satisfaction have been found to relate to both attitude measures, although not all of these determinants were included in the same study.

It is possible that the apparent empirical similarity between the constructs noted above is due to inconsistent definitions and variations in measures used in previous studies, and the absence of theoretical frameworks to guide variable selection.
Those problems are less of a concern in this paper, given the nature of the theoretical basis we use to identify constructs and the model we develop, which permits a systematic examination of the determinants of attitudes both within a single study and over two different cultural contexts.

\section{Data and Empirical Specification}

\section{Data}

The data were collected through a questionnaire survey in 1987 of unionized employees in Sweden and Canada. The Swedish sample included 26 diverse unionized professional occupations such as university professors, doctors, lawyers, clergymen, military officers, economists, psychologists, and other professionals affiliated with SACO, the professional union federation in Sweden. The questionnaire was sent to 2,900 randomly selected union members and was accompanied by a letter from the President of SACO requesting their cooperation in an international research project. A total of 1,995 responses were obtained, for a response rate of $68.7 \%$. The high response rate is probably attributable to the professional nature of the sample, since highly educated professionals are more likely than most people to be willing to participate in a survey designed for international and comparative research.

In Canada, the survey was sent directly to the homes of 1,054 union members randomly selected from the membership rosters of the two largest unions representing workers in retail food sales and distribution. The Canadian sample consisted of meatcutters, warehouse workers, retail clerks, and cashiers. As in the Swedish survey, participants were requested to return the completed questionnaires directly to the researchers using postage-paid envelopes. A total of 482 questionnaires were returned, for a response rate of $45.7 \%$.

After case-wise deletions for missing values, the usable sample sizes were 1,675 and 472, respectively, for Sweden and 
Canada. The translation-backtranslation method was used in the application of the questionnaire to the Swedish sample.' In both countries, extensive discussions were held with both academicians and union officials (leaders and research officers) to ensure that the questions would be understood in the same way by union members in the two samples.

Although Sweden and Canada differ in terms of their culture and their political, economic, and industrial relations systems, both are advanced industrial nations with a relatively high union density. Canadian union density was about $36 \%$ during the 1980 s, and Swedish union density remained at about $85 \%$ during the same period (Chaison and Rose 1991).

The two countries differ markedly in organization at the national level. Canadian unions are primarily organized on an industrial basis, whereas Swedish unions are organized into three primary federations, one each for blue-collar, whitecollar, and professional members. Within each federation, however, unions are organized on both industrial and occupational lines. Collective bargaining in Sweden is highly centralized and carried out at the level of the federation in terms of wages, although there has been a strong movement toward increased decentralization during the past five years (see Abrahamson 1992). Collective bargaining in Canada tends to be more decentralized to the local union level.

Although exceptions may exist, Canadian unions generally have traditional goals, focusing on "business unionism," whereas Swedish unions hold broader

\footnotetext{
${ }^{1}$ The method is the following: the English version of the questionnaire is translated into Swedish by one person; when it has been determined that the Swedish version reflects accurately the meaning of the questions in English, a second person retranslates the questionnaire from Swedish back to English; and finally, the original English version and the English version translated from Swedish are compared to determine whether the questions have the same meaning. The two different people responsible for the translation and retranslation (or. "back translation") are chosen based on their knowledge of the sample, the subject matter and field of research, and their knowledge of the language.
}

social goals that go beyond the traditional collective bargaining relationship, such as reducing wage inequality, administering the unemployment insurance system, and increasing industrial and economic democracy. The diversity of the samples facilitates an assessment of the crosscultural generalizability of the propositions examined in this paper.

\section{Empirical Specification}

We use previous research and Fishbein and Ajzen's theory of reasoned action for guidance in selecting variables that could affect union attitudes. Two factors underlie our choice of Fishbein and Ajzen's theory. First, the theory induces a consideration of the processes underlying attitude formation, which Mowday, Porter, and Steers (1982:71-72) note has been absent in much of the previous organizational attitudinal research. Second, the theory has been used successfully to generate models of attitude formation in studies of a number of subjects in the social sciences, such as consumer behavior, political science, and, recently, union voting intent (see, for example, Montgomery 1989).

Most relevant to this study is the implication of Fishbein and Ajzen's model that people process information in generating new beliefs, or combine new information with currently held beliefs to form an attitude toward the union. At least three different processes underlie belief formation (Fishbein and Ajzen 1975:134). Beliefs may be formed by accepting information provided by an outside source, such as the media (informational belief); they may be formed through direct experiences with the union (descriptive belief); and they may be formed by inferences about the union made on the basis of prior descriptive beliefs or inferences (inferential belief). One's attitude toward a union is determined by the sum of one's salient beliefs about the union; and attitudes, along with subjective norms, cause behavior.

Fishbein and Ajzen's information processing view directs our attention to several variables germane to union attitude formation that have been absent 
from previous research-notably, the sources of information about the union that members are exposed to, and what unions do to inform and educate their members. Combining these aspects of Fishbein and Ajzen's theory with the results of previous research facilitates the development of a more comprehensive model to examine union attitudes. Below, the independent variables included in the model are presented and discussed. See Table 1 for a description of measures and summary statistics.

The model takes the following general functional form:

(1) Union Attitudes $=b_{0}+b_{1}$ (variables measuring beliefs about unions)

$+b_{2}$ (variables measuring received

information about the union)

$+b_{3}$ (control variables) + error.

Belief variables. Consistent with previous research (Kochan 1978) and Fishbein and Ajzen (1975), two measures of general beliefs about unions are included in the model. Workplace instrumentality (wORKINST) is measured by a five-item Likerttype scale with higher values indicating more positive agreement. This first measure includes statements asserting that unions improve wages, benefits, working conditions, and job security. A positive relationship is expected with our attitude measures. The second, BIGLABOR, is measured by a four-item Likert-type scale (reverse coded) and includes statements asserting that unions have grown too big, interfere with good relations between management and workers, and are the primary cause of inflation. A negative relationship is expected between this measure and both union attitudes.

The literature is inconclusive regarding the causal direction between general beliefs about unions and attitudes toward a specific union. Although studies have reported causal relationships between general beliefs about unions and specific behavioral intentions such as the intention to vote for a union, no direct examination of the causal relationship between general beliefs and union attitudes exists in the literature. Brett and Hammer (1982) suggest that current beliefs about unions can serve as filters that shape the development and acquisition of future attitudes toward the union, resulting in a cyclical relationship whereby beliefs and specific attitudes constantly reinforce each other. Although we are uncertain of the direction of causality, we allow for a cyclical effect.

Information variables. Although our data do not contain measures of beliefs about each member's union, but only beliefs about unions in general, the data do contain respondents' answers to questions regarding whether they received information about the union from various sources-specifically, through union socialization activities (new member orientation programs) at the time of joining; regular news publications of the union; previous participation in union activities; and inferences from the attitudes and opinions of friends and co-workers. Because of the absence of direct measures of beliefs about the local union in our data, we are forced to make links between information and union attitudes.

Socialization into the union (social) is measured by a seven-item scale indicating the extent to which union orientation programs provided information to the member about the union at the time of joining; ${ }^{2}$ the helpfulness of the member's steward and other union officials; and the extent to which assistance was received from other members. Fishbein and Ajzen's work, as well as other research (Gallagher and Clark 1990; Fullagar and Barling 198), leads us to expect a positive relationship between early socialization and union attitudes.

A second source of information about the union likely to affect member attitude formation consists of the information unions regularly disseminate to members and potential members via union publica-

\footnotetext{
${ }^{2}$ The average union tenure is 11.87 years in Sweden and 7.57 years in Canada; therefore, socialization information refers to occurrences over a reasonably long term. Imperfect recall by the respondents could, however, bias the results.
} 
Table 1. Summary Variable Definitions and Descriptive Statistics.

\begin{tabular}{lr}
\hline Variable & Mean Std. Dev. \\
\hline Union Membership Tenure & \\
Sweden (in years) & 11.87 \\
Canada (inyears) & 8.63
\end{tabular}

6.80

Workplace Instrumentality (WORKINST)

Multi-item 5-point scales measuring perceptions of unions' instrumentality in the workplace ( 1 = strongly disagree, 5 = strongly agree).

Sweden (5 items), Alpha $=.76$

$3.24 \quad .62$

Canada (5 items), Alpha $=.85$

Big Labor Image (BIGLABOR)

Multi-item 5-point scales measuring image of unionism in general.

Sweden (4 items), Alpha $=.70$

Canada (4 items), Alpha $=.78$

Lower Forms of Union Participation (LOPART)

Multi-item scales measuring instances of modest forms of participation in various union-related activities in years preceding the current year (e.g., voting in elections, attendance at meetings).

Sweden $(6$ items, $1=$ yes, $0=$ no), Alpha $=.80$

Canada ( 6 items, $1=$ yes, $0=$ no), Alpha $=.80$

Higher Forms of Union Participation (HIPART)

Multi-item scale measuring active participation in various union activities in years preceding the current year (e.g., being an elected union officer, campaigning).

Sweden ( 6 items, $1=$ yes, $0=$ no), Alpha $=.80$

Canada ( 6 items, $1=$ yes, $0=$ no), Alpha $=.80$

Note: The specific items used to create this measure vary across the samples, since questions wree chosen based on relevance to the unions in each of the two countries.)

Reading Union Publications (READ)

Single-item scale reflecting whether members read union publications regularly.

Sweden $(1=$ yes, $0=$ no)

Canada $(1=$ yes, $0=$ no $)$

Socialization Experiences (SOCIAL)

Multi-item measures of the occurrence of instances of union socialization during the first year of union membership (e.g., exposure to a union orientation program at the time of joining).

Sweden ( 7 items, $1=$ occurred, $0=$ did not occur)

Canada ( 7 items, $1=$ occurred, $0=$ did not occur)

Friends' Views About Unions (FRIENDS)

A two-item scale measuring friends' views about unions.

Sweden ( $1=$ don't like unions, $5=$ strongly support unions)

Canada ( 1 = don't like unions, $5=$ strongly support unions)

Co-workers' Views About Unions (COWORKERs)

A two-item scale measuring co-workers' views about unions.

Sweden ( $1=$ don't like unions, 5 = strongly support unions)

Extrinsic Satisfaction (EXTSAT)

Multi-item 5-point scales measuring satisfaction with various extrinsic aspects of the job $(1=$ very dissatisfied, $5=$ very satisfied $)$.

Sweden (5 items), Alpha $=.82$ 
Table 1. (continued)

Variable

Mean Std. Dev

Intrinsic Satisfaction (INTSAT)

Multi-item 5-point scales measuring satisfaction with various intrinsic aspects of the job

( 1 = very dissatisfied, 5 = very satisfied).

Sweden $(5$ items), Alpha $=.84$

$3.66 \quad .78$

Canada (5 items), Alpha $=.88$

$3.38 \quad .85$

Satisfaction with Union Representation (UNSAT)

Multi-item 5-point scales measuring satisfaction with union performance in collective bargaining, member-union relations, and union effectiveness at improving the quality of work life $(1=$ very dissatisfied, $5=$ very satisfied $)$

Sweden $(8$ items), Alpha $=.83$

Canada ( 8 items), Alpha $=.86$

$2.97 \quad .56$

$2.89 \quad .65$

Union Commitment (UNCOM)

Multi-item 5-point scale containing items reflecting respondents' commitment to the local union ( 1 = strongly disagree, $5=$ strongly agree).

Sweden (12 items), Alpha $=.82$

Canada (12 items), Alpha $=.88$

$3.31-.52$

$3.16 \quad .75$

tions. A single-item Likert-style scale measures the extent to which the respondent has read union newsletters in the past (READ). It is hypothesized that regular reading of these union publications in the past will positively affect current attitudes. A problem of causality exists here: it is possible that only committed members read union publications on a regular basis, whereas our model assumes that information sources are exogenous. It is also possible, however, that there is a cyclical effect between regular information access and attitudes: committed or satisfied members read more, and that additional exposure to union literature may increase their commitment or satisfaction (or both). Since our measure reflects past reading, it is consistent with the cyclical perspective. A positive relationship with union attitudes is expected.

Because direct experiences with the union may lead to formation of descriptive beliefs (Fishbein and Ajzen 1975:132), information obtained from previous participation in union activities may shape union attitudes. In this study, members answered questions about their participation in union activities in preceding years. It is expected that previous participation will be positively related to union commitment.

The literature suggests two different views of the relationship between union attitudes and participation. One view holds that union commitment is a precursor to participation in union activity (for example, Fullagar and Barling 1987); the other (for example, Salancik 1977) suggests a constant cyclical effect in which people develop attitudes of commitment to maintain consistency with their behavior (participation). Mowday, Porter, and Steers (1982) noted that attitude and behavior may be mutually reinforcing: people who participate will be more committed, and their greater commitment will, in turn, lead to greater participation. Magenau, Martin, and Peterson (1988) also found that past participation is a precursor of commitment. Since the measure of participation used in this study reflects previous participation in relation to current union commitment and union satisfaction, our measure is consistent with the cyclical perspective noted above, and the problem of reverse causality is not important. The cyclical perspective also holds true for a positive union satisfaction-participation relationship.

As in previous research, the measure of participation was divided to reflect different levels of participation. Active (HIPART) participation (being an elected union official, being a shop steward, being involved in election campaigns, and help- 
ing to organize activities) is measured by a composite 6-item "yes-no" scale. Lower forms of participation (LOWPART) include attending union meetings and voting in contract ratification and elections. LowPART, measured by a six-item "yes-no" composite scale, corresponds to "passive" participation, noted by Nicholson, Ursell, and Blyton (1981). It is expected that HIPART will evidence a stronger relationship with union attitudes (due to increased access to information) than LOWPART.

Since other individuals are also a source of information about the union, we postulate that friends' and co-workers' opinions about and attitudes toward the union will affect the respondents' attitude toward the union. Two-item Likert-type composite scales were created. They include items indicating the degree to which friends (FRIENDS) and co-workers (COWORKERS) approve of the local union, and the degree to which they discuss the union outside of the work setting. Our measures are consistent with those used by Montgomery (1989), who noted that normative variables such as the opinions of friends affect attitude. A positive relationship is expected.

Control variables. Two measures of job satisfaction are included as control variables, given previously noted relationships between these variables and the dependent variables (Kochan 1979; Fiorito et al. 1988; Gordon, Beauvais, and Ladd 1984). Brief and Rude (1981) noted that attitudes toward the local union are influenced by an employee's affective reactions to previous economic consequences of his or her immediate employment. In essence, past actions of an employer serve as stimuli affecting the employee's perception of unions' instrumentality. Extrinsic satisfaction (EXTSAT) is measured by a composite five-item, Likert-type scale adapted from the Minnesota Satisfaction Questionnaire. It includes items such as satisfaction with pay, benefits, job security, and promo-. tions. Intrinsic satisfaction (INTSAT), a five-item composite Likert-type scale, is measured by items denoting satisfaction with the work itself.

Unlike much of the previous research that has reported relationships between union attitudes and demographic variables such as age, gender, education, and tenure (Gallagher and Clark 1989; Fullagar and Barling 1987), our study does not include measures of these worker characteristics, because there is no clear theoretical rationale for doing so.

The full form of the model, inclusive of all measures under various classes of predictors, is the following:

$$
\begin{aligned}
& \text { UNCOM, UNSAT }=b_{0}+b_{1} \text { SOCIAL } \\
& +b_{2} \text { HIPART }+b_{3} \text { LOWPART }+b_{4} \text { READ } \\
& +b_{5} \text { WORKINST }+b_{6} \text { BIGLABOR } \\
& +b_{7} \text { FRIENDS }+b_{8} \text { COWORKERS } \\
& +b_{9} \text { EXTSAT }+b_{10} \text { INTSAT }+ \text { ERROR }
\end{aligned}
$$

UNCOM and UNSAT are the dependent variables for union commitment and union satisfaction, respectively. UNCOM, measured by a twelve-item Likert-style composite scale (adapted from the Gordon et al. [1980] commitment questionnaire), includes concepts such as loyalty to the union and willingness to work for the union. ${ }^{3}$ UNSAT is a composite of eight Likert-style items used in the Quality of Employment Survey (1977). It includes satisfaction with union performance on bread and butter issues, satisfaction with internal member-union relations, and satisfaction with union efforts to improve the quality of work life. Both dependent variables in both samples exhibited a high level of reliability (see Table 1 ).

\section{Methods}

Given the apparent inconsistency of both conceptual and empirical distinctions

\footnotetext{
${ }^{3}$ Although Gordon et al. (1980) suggested that union commitment consists of four dimensions (loyalty, willingness to work, responsibility to the union, and belief in unionism), our measures correspond to research by Friedman and Harvey (1986) and Klandermans (1989), who suggested that a two-factor model (with an attitudinal factor consisting of loyalty and beliefs, and a behavioral intentions factor) is a more parsimonious representation of union commitment. The commitment measures used in both samples reflect the attitudinal and behavioral factors noted above. Both scales show a high degree of reliability (a high Cronbach's alpha). For further details on the scales used, see Kuruvilla (1989).
} 
between union commitment and union satisfaction, we first examine the empirical distinction between the constructs via a confirmatory factor analysis using the LISREL VII computer program. Two measurement models were estimated. The first model hypothesizes that two factors, UNCOM and UNSAT, underlie the data. The second model hypothesizes that only one factor underlies the data; in essence, this model assumes that the two factors are the same underlying construct. Following conventional procedures, we report the various goodness of fit indices provided by LISREL, ${ }^{4}$ but unlike most studies, ours relies on the Normed Fit Index (NFI) (Bentler and Bonnet 1980), which compares the fit of the hypothesized models to the null model (an unconstrained model that hypothesizes that each item is a separate factor of its own) to draw conclusions. An NFI ranges from zero to one, with higher values indicating better fit.

Second, the union attitude formation model was estimated. Although a canonical correlation is suggested as being appropriate when there are two related dependent variables, we estimated the model using both canonical correlation and standardized regression procedures. Because the results yielded by the two procedures do not differ markedly, we report and discuss the more "conven-

\footnotetext{
${ }^{4}$ Various indices are commonly used to evaluate the goodness of fit. LISREL provides a goodness of fit index (GFI). It is an index of the amount of variance and covariance among the items accounted for by the model. The adjusted goodness of fit index (AGFI) denotes the variance and covariance accounted for by the model adjusted for the degrees of freedom in the model. The normed fit index (NFI) compares the fit of the model to the null model (Bentler and Bonnett 1980). The parsimonious fit index (PFI) corrects the NFI by adjusting for the degrees of freedom for the model (James, Mulaik, and Brett 1982). The root mean square residual (RMSR) is the result of the subtraction of the hypothesized covariance matrix from the sample covariance matrix (Joreskog and Sorböm 1988). For the GFI, AGFI, NFI, and PFI the values range from zero to one, with higher values representing a better fit. For the RMSR, also on a $0-1$ scale, lower values represent a better fit.
}

tional" regression results. ${ }^{5}$ Note that the significance levels reported in Table 3 are based on tests of the unstandardized coefficients.

\section{Results}

The results indicate that union commitment and union satisfaction are distinct attitude constructs and are associated with different independent variables in both Sweden and Canada. Below, we discuss the results in terms of the differences between union satisfaction and union commitment, and the similarity of the results between the two countries. A later section examines those instances in which the results differed across the two countries.

UNCOM-UNSAT differences. The confirmatory factor analysis results reported in Table 2 and the standardized regression results suggest that union commitment and union satisfaction are empirically different attitudes. In both countries, all the various goodness of fit indicators tell the same story: the model hypothesizing that two constructs underlie the data provides a better fit than the model hypothesizing that only one construct underlies the data. The NFI for the two-factor model in the Swedish sample is .819 , compared to .581 for a single-factor model. In the Canadian case, the NFI of .904 for the two-factor

\footnotetext{
${ }^{5}$ Although the confirmatory factor analysis results indicate that UNCOM and UNSAT are empirically distinct, the correlation between them suggests that they are not independent. Canonical correlation is often used in such cases. Canonical relationships are normally interpreted by forming a structure correlation matrix between the scores on the original dependent variables and the scores on their canonical variates. Analysis of the structure correlations between scores on the predictor variables and the canonical variates of the criterion variables produces results similar to our regression results in both samples, after we follow Cooley and Lohnes's (1971) rule of thumb of disregarding coefficients of .30 and below. In both samples, the canonical weights (standardized canonical correlations) for UNCOM are higher than those for UNSAT (.825 and .354 for Sweden, and .701 and .390 for Canada), indicating that the set of predictors is more closely related to uNCoM than to UNSAT. Further details on these results are available from the authors.
} 
Table 2. Confirmatory Factor Analysis Results for Union Attitudes in Sweden and Canada. ${ }^{a}$

\begin{tabular}{lrllllll}
\hline Model & Chi-Square & $D F$ & $p<$ & GFI & AGFI & RMRS & NFI \\
\hline Sweden & & & & & & & \\
NULL & 17186.48 & 230 & .000 & .359 & .230 & .273 & - \\
1-Factor & 7198.28 & 210 & .000 & .657 & .588 & .112 & .581 \\
2-Factor & 3100.60 & 191 & .000 & .851 & .764 & .061 & .819 \\
Canada & & & & & & & \\
NULL & 4283.50 & 190 & .000 & .267 & .190 & .361 & - \\
1-Factor & 1035.93 & 170 & .000 & .734 & .671 & .091 & .758 \\
2-Factor & 409.96 & 161 & .000 & .909 & .881 & .042 & .904 \\
\hline
\end{tabular}

${ }^{a}$ Within each sample, chi-square difference tests indicate that the null, one-factor, and two-factor models are significantly different $(p<.001)$ from each other.

model is substantially higher than the NFI of .758 for a single-factor model. ${ }^{6}$ In both countries, the chi-squares of the two-factor model differ significantly $(\mathrm{p}<.001)$ from the chi-squares of the single-factor model and the null model. Maximum likelihood estimates of the factor loadings (not reported here due to space constraints) show relatively high loadings on both constructs in both samples. ${ }^{7}$ The consistently similar results across countries indicate that UNCOM and UNSAT are empirically different attitude constructs.

Differences between UNCOM and UNSAT are also apparent from the results of the tests of our model as reported in Table 3. In general terms, the differences in the R-squares for both UNCOM and UNSAT within each sample suggest the empirical difference between the constructs. The model explains $48 \%$ of the variance in UNCOM and $36 \%$ of the variance in UNSAT

\footnotetext{
${ }^{6}$ Bentler and Bonnet (1980) suggest that an NFI over .90 indicates excellent fit. By this criterion, our Canadian model has excellent fit, but the Swedish model's fit $(.81)$ is more modest. We are interested, however, in the NFI relative to alternate models, and in that respect, the two-factor NFI in Sweden performs well, improving substantially over the fit of alternative factor models.

${ }^{7}$ LISREL (maximum likelihood) estimates of the factor loadings for the UNCOM factor in Sweden range from .588 to .718 , and for UNSAT the loadings range from .535 to .898 . The ranges of factor loadings for UNCOM and UNSAT in Canada were $.571-.773$ and $.623-.718$, respectively. Note that a simple exploratory factor analysis (principal components with varimax rotation) yields a two-factor structure in both samples, with the satisfaction and commitment items loading on two separate factors.
}

in the Swedish sample and $67 \%$ and $56 \%$ of the variance in UNCOM and UNSAT, respectively, in Canada. A more formal test of the difference between UNSAT and UNCOM, however was conducted via an examination of the hypothesis that all non-intercept parameters (within each sample) were the same for both dependent variables. The results indicate that the hypothesis that all non-intercept parameters within samples (comparing UNSAT and UNCOM equations within each country) are the same can be rejected at the $\mathrm{p}<$ .001 level $(F=37.035$, DF 9,436 for Canada; $F=40.568$, DF 9,1426 for Sweden). This result suggests that the independent variables are differently related to UNCOM and UNSAT - further evidence that those two constructs are distinct.

The tests of the model indicate that many of the independent variables have different influences on UNCOM and UNSAT. The results for the various independent variables are reported in Table 3 and discussed below.

In the Canadian sample, beliefs about union instrumentality (WORKINST) are positively and significantly related to both UNCOM and UNSAT $(p<.001)$, indicating that positive beliefs about unions in general condition members' perceptions about their own unions to a considerable extent. This variable is the strongest predictor of union attitudes, although the possibility of reverse causality cannot be ignored. In contrast, the more negative "big labor" image (BIGLABOR) is negatively related to UNCOM, but not to UNSAT. As 
Table 3. Determinants of Union Attitudes in Sweden and Canada: Standardized Regression Estimates.

\begin{tabular}{|c|c|c|c|c|}
\hline \multirow{2}{*}{$\begin{array}{l}\text { Independent } \\
\text { Variable }\end{array}$} & \multicolumn{2}{|c|}{$\begin{array}{c}\text { Union } \\
\text { Commitment }\end{array}$} & \multicolumn{2}{|c|}{$\begin{array}{c}\text { Union } \\
\text { Satisfaction }\end{array}$} \\
\hline & Sweden & Canada & Sweden & Canada \\
\hline WORKINST & $.349 * * *$ & $.400^{* * *}$ & $.395 * * *$ & $.589 * * *$ \\
\hline BIGLABOR & $-.178 * * *$ & $-.230^{* * * *}$ & .046 & .016 \\
\hline SOCIAL & $.056 * *$ & $.129 * * *$ & $.067 * *$ & .023 \\
\hline LOWPART & $.054 *$ & .021 & .017 & -.032 \\
\hline HIPART & $.276 * * *$ & $.164^{* *}$ & -.002 & .096 \\
\hline READ & $.057 * *$ & .032 & .008 & -.037 \\
\hline FRIENDS & $.100 * * *$ & $.131^{* *}$ & .046 & -.049 \\
\hline COWORKERS & .016 & .033 & $.120 * * *$ & $.129 * * *$ \\
\hline EXTSAT & $-.053^{*}$ & .044 & $.327 * * *$ & $.198^{* * * *}$ \\
\hline INTSAT & -.036 & .052 & $-.070^{* *}$ & $.103^{*}$ \\
\hline $\mathrm{R}^{2}$ & .484 & .680 & .369 & .579 \\
\hline Adj. $R^{2}$ & .480 & .668 & .364 & .563 \\
\hline $\mathbf{N}$ & \multicolumn{2}{|c|}{1675} & \multicolumn{2}{|c|}{472} \\
\hline
\end{tabular}

${ }^{*}$ Statistically significant at the .05 level; ${ }^{* *}$ the .01 level; ${ }^{* * *}$ the .001 level. Significance levels are based on tests of the unstandardized coefficients.

Table 3 indicates, the results for workinst and BIGLABOR are similar for the Swedish sample also. This result suggests that the negative evaluation of unions in general is not associated with evaluations of one's own union, although positive beliefs about unions in general are related to both union attitudes.

The union information variables appear to have different effects on UNCOM and UNSAT, suggesting a pattern of difference between the two constructs. Social and HIPART are related to union commitment in Canada, but not to union satisfaction. In the Swedish sample, HIPART, LOWPART, and READ are positively related to union commitment but not to union satisfaction. SOCIAL, however, is related to both union attitudes in the Swedish sample.

The significant relationship noted between these variables and UNCOM is consistent with the notion that UNCOM develops over time, and is more stable than UNSAT (all these variables reflect information obtained in the past). In contrast, with the exception of social in the Swedish sample, none of the information variables is significantly related to UNSAT. The unexpected positive relationship between soCIAL and UNSAT in Sweden is probably attributable to union members seeing union orientation programs for new members as part of union efforts to keep in touch with the membership. This interpretation is consistent with the finding in previous Swedish studies that keeping members informed is an important determinant of union satisfaction (Jarley, Kuruvilla, and Casteel 1990).

It appears that friends' attitudes and opinions do not influence respondents' attitudes in the same way that co-workers' attitudes and opinions do. In both samples, FRIENDS was positively and significantly $(\mathrm{p}<.001)$ related to UNCOM, whereas coworkers was positively and significantly $(p<.001)$ related to UNSAT. We can only speculate as to the explanation for this result. Perhaps the strong positive relationship between FRIENDS and UNCOM reflects the fact that friends often have shared values, and one person's values and identification with the union are likely to mirror and reinforce the values and identification with the union of that person's friend. Co-workers, on the other hand, may not have similar values, but they share experiences in connection with the union; and the positive relationship between coworkers and UNSAT may reflect the influence of co-workers' opinions about the union on evaluations of union performance by the respondent.

In the Canadian sample, both measures of job satisfaction, EXTSAT and INTSAT, have strong positive relationships with UNSAT and 
no significant relationship with unCOM. In the Swedish sample also, EXTSAT and INTSAT are more strongly related to UNSAT than to UNCOM (although the direction of the effect is different). The stronger relationship between the job satisfaction measures and UNSAT than between those measures and UNCOM is consistent with the notion that UNSAT is evaluative and reflects reactions to union performance on work-related issues, whereas UNCOM reflects an identification with the union, its goals and values. It appears that union members hold the union accountable for job-related outcomes, and evaluate the union favorably or unfavorably based on those outcomes, but that such evaluations have little effect on members' long-term commitment to the union.

In both countries, the models appear to explain a greater proportion of the variance in UNCOM than in UNSAT, suggesting that the model may be underspecified in the UNSAT equation. There is enough evidence here, however, to suggest that UNCOM and UNSAT are empirically separate attitude constructs, and this conclusion is further buttressed by the confirmatory factor analysis results. The different relationships between various independent variables and UNSAT and UNCOM are consistent with Mowday et al.'s (1982) notion that commitment represents an identification with the union as a whole that develops over time, whereas union satisfaction is more evaluative, and closely related to job-related outcomes such as satisfaction with pay, benefits, and other extrinsic and intrinsic job characteristics.

Unlike previous research, our model omits demographic variables, since they do not appear to determine attitude formation, even though they may be correlated with it. ${ }^{8}$ For comparative pur-

\footnotetext{
${ }^{8}$ Gallagher and Clark (1989) review the findings with respect to the relationship between demographic variables and union commitment. They note that the results are generally inconclusive, with wide variations across studies for measures such as age, education, and tenure. They also note that more often than not, gender (being female) is positively associated with commitment. The demographic variables are not included in the model in this paper because we can think of no theoretical rationale for doing so.
}

poses, however, the model was re-estimated with age, gender, union tenure, and education included as independent variables. The results of this analysis (not reported here) indicate only marginal increases in the explanatory power of the model in both samples; the $\mathrm{R}^{2}$ for both UNCOM and UNSAT increased by one or two percentage points only.

Differences between Sweden and Canada. Comparing the results across the two countries presents a problem that could, paradoxically, become an advantage. The problem is the potential confounding of nationality with type of union. The fact that the Swedish sample consists of professionals and the Canadian sample consists of blue- and white-collar workers could make interpretation of the results across the countries difficult or impossible if the results for the two countries differ dramatically; but if the results do not differ significantly, then the vast differences in union and nationality types across samples actually strengthen the force of the conclusion that the observed patterns are universal in character.

We have already noted many similarities between the results for Sweden and those for Canada. In particular, the results for the belief variables, the information variables, and the normative variables are remarkably similar in the two countries. We now turn our attention to the few differences that were found across the samples-differences that may flag some respects in which nationality and union type are influential.

Although ExTsat, as expected, was positively and significantly $(\mathrm{p}<.001)$ related to UNSAT in Sweden and Canada, INTSAT was negatively related to UNSAT in Sweden. This result suggests that in Sweden, employees who are more satisfied with intrinsic aspects of the job tend to be less satisfied with their union. This result appears consistent with the professional nature of the sample in Sweden. Professionals and white-collar workers in Sweden are increasingly loath to join unions and have shown increased signs of dissatisfaction with their unions, and recent declines in union membership in Sweden 
have been heaviest within their ranks (see Ahlén 1992; LO 1990a, 1990b). Professional jobs such as those of doctors, lawyers, and academicians also have a more specialist focus than blue-collar work, and the inability of unions to address uniquely professional concerns may account for their dissatisfaction with their unions and for the negative relationship between INTSAT and UNSAT.

The negative relationship between ExTSAT and UNCOM in Sweden is largely explained by white-collar and professional employees' dissatisfaction with the centralized bargaining model and the goals of the "solidaristic" wage policy of the unions, which necessarily involved some amount of wage sacrifice on the part of highly paid employees (Pontusson and Kuruvilla 1992:7).

The correlation between UNCOM and UNSAT $(\mathrm{r}=.34)$ is also lower in Sweden than in Canada ( $r=.64)$. In this case, the primary explanation, we believe, is a "national type" explanation rather than a "union type" explanation. Specifically, differences between the two countries in the role and activities of the local union may be responsible. Canadian local unions perform typical "business union" functions. Swedish unions, in contrast, undertake a number of activities beyond the traditional scope of union representation-notably, the administration of the unemployment compensation system, worker education and training via unionsponsored and -directed training programs, representation in various local governmental and municipal bodies, and political activity geared toward increasing industrial and economic democracy and support of the welfare state concept. Swedish workers' identification with local union goals in these matters is a factor in determining their commitment to the local union. Since, in this study, satisfaction with union representation is measured by union performance on work-related issues such as pay and benefits, it is not surprising that there is a lower observed correlation between UNCOM and UNSAT in Sweden than in Canada. That is, it is possible that in the interests of standard- ization of the questionnaire, we have not adequately measured aspects of union satisfaction in Sweden. The broader nonwork-related goals of Swedish local unions are a likely explanation for why Swedish workers are simultaneously more committed to the union and less satisfied with union performance on various job-related dimensions than are Canadian workers.

We are unable to fully explain why READ is positively related to commitment in Sweden, but not in Canada. One possible explanation is that the frequency of union publications is greater in Sweden. Our investigation indicates that the Swedish unions in this sample publish, on average, one monthly newsletter that is mailed to respondents' homes, whereas the Canadian unions publish newsletters on a sporadic basis and do not send them to members' homes, but simply leave them at workplace locations. Although the content of the newsletters may influence the members' decision to read the articles, the Canadian unions in this sample provide less of an opportunity for their members to read about the union.

Apart from these differences, the determinants of attitude formation appear to be remarkably similar in the two countries. A test of the hypothesis that each nonintercept (unstandardized) parameter for both dependent variables is the same across samples (that is, in a comparison of the UNCOM equation in Sweden with the uncom equation in Canada, and of the UNSAT equation in Sweden with the UNSAT equation in Canada) cannot be rejected for most variables. This pattern of similarity is further evidence of the generalizability of the model in the two countries. ${ }^{9}$

\footnotetext{
9 This test examines whether or not the parameter values associated with one independent sample are the same as those associated with another independent sample. The T-test used here is analogous to the Z-test reported by Cohen and Cohen (1983:111), and is calculated as follows:$$
t_{(n 1+n 2-1)}=\frac{\beta_{1}-\beta_{2}}{\sqrt{\operatorname{Se}_{1}{ }^{2}+\mathrm{Se}_{2}{ }^{2}}}
$$

The results indicate that, except in the case of BIGLABOR and EXTSAT in the UNCOM equation, and
} 


\section{Discussion}

The first objective of this study was to examine the distinction between union commitment and union satisfaction. Although the results of previous studies suggested that these two concepts may not be as distinct empirically as they are conceptually, our results suggest that there are empirical differences between the two constructs, differences that are consistent with the conceptual differences noted in the literature. We find that these differences exist across the two countries, suggesting some degree of generalizability.

The second objective was to identify, based on theory, key variables that influence union attitudes. The results suggest that in both countries, members who have had several forms of contact with the union-new member orientation programs, previous participation in union activity, and regular reading of union newspapers-are more likely to be committed to the union, but these variables are unrelated to union satisfaction. Friends' opinions of and attitudes toward unions also appear to influence members' commitment toward their union, but not their satisfaction with the union. Conversely, co-workers' job satisfaction and attitudes toward the union are positively associated with respondents' union satisfaction, but are unrelated to their union commitment. The results also show that respondents' beliefs about unions generally have a significant and powerful impact on their attitudes toward their own unions, particularly if the general beliefs are positive. The similarity of these results across two quite different cultural contexts provides some evidence of the generalizability of the model.

We admit that we cannot infer causal relationships; longitudinal data are better suited to test for causal links identified by a theory than are cross-sectional data such as those we have used. In this study, we selected the variables to be tested based on a theoretical framework, and the results

INTSAT in the UNSAT equation, none of the parameters are significantly different across samples. are consistent with that theory. Although longitudinal data would have provided a better test of our model, we feel that the potential determinants of union satisfaction and commitment identified in this paper have implications for both unions and further research.

Although industrial relations characteristics such as the goals and strategies of unions do appear to influence union commitment and union satisfaction, the results in both countries imply that attitudes toward unions are also dependent on what the unions themselves do to shape them. Simply put, unions can, through purposefully designed actions, influence their members to evaluate them positively. Given the apparent generalizability of our study, this finding has important implications for unionists not only in Sweden and Canada but in other countries as well.

In particular, the association we have found between members' socialization into the union and their commitment to it seems highly relevant to the U.S. labor movement, in light of the negative image of unions that is common among workers and the prevalent dissatisfaction with unions among members in this country. New employees entering the workplace often bring with them many misconceptions about unions. As one corrective, new member orientation programs (which are largely under the control of unions themselves) can provide newcomers with accurate information about the union's contributions. Introducing new member orientation programs is one of the key recommendations of the AFL-CIO (1985) report on the changing situation of workers and their unions, but many U.S. unions have done little on this score. Second, U.S. unionists would do well to keep members continually informed, given the strong association we find between regular reading of union newspapers and union commitment. Finally, our finding that the opinions of friends and co-workers are significantly associated with members' union attitudes suggests that increasing member participation in union organizing might be helpful, and provides some empirical justification for the AFL-CIO's "one-on-one" organizing programs. 


\section{REFERENCES}

Abrahamson, Bengt. 1992. "Unions' Structural Change." Paper Presented at the Symposium on Emerging Union Structures: An International Comparison. Clark University, Worcester, Mass., March 9-10.

AFL-CIO Committee on the Evolution of Work. 1985. The Changing Situation of Workers and Their Unions. Washington, D.C.: AFL-CIO.

Ahlén, Kristina. 1992. "Union Legitimacy: Members' Perceptions of Union Government." Paper Presented at the Symposium on Emerging Union Structures: An International Comparison. Clark University, Worcester, Mass., March 9-10.

Allport, Gordon W. 1935. "Attitudes." In C. Murchison, ed., A Handbook of Social Psychology. Worcester, Mass.: Clark University Press, pp. 654-59.

Asher, Herbert B. 1983. "Causal Modeling." Series on Quantitative Applications in the Social Sciences. Beverly Hills: Sage University Papers, pp. 1-15.

Bentler, P. M., and D. G. Bonett. 1980. "Significance Tests and Goodness of Fit in the Analysis of Covariance Structures." Psychological Bulletin, Vol. 88, No. 3 (November), pp. 588-606.

Bigoness, William J., and Henry L. Tosi. 1984. "Correlates of Voting Behavior in a Union Decertification Election." Academy of Management Journal, Vol. 27, No. 3 (September), pp. 654-59.

Brett, Jeanne, and Tove Hammer. 1982. "Organizational Behavior and Industrial Relations." In T. A. Kochan, D. J. B. Mitchell, and L. Dyer, eds., Industrial Relations Research in the 1970's: Review and Reappraisal. Madison, Wis.: Industrial Relations Research Association, pp. 221-81.

Brief, Arthur P., and E. Dale Rude. 1981. "Voting in Union Certification Elections: A Conceptual Analysis." Academy of Management Review, Vol. 6, No. 2 (A pril), pp. 261-67.

Chaison, Gary N., and Joseph B. Rose. 1991. "The Macrodeterminants of Union Growth and Decline." In G. Strauss, D. G. Gallagher, and Jack Fiorito, eds., The State of the Unions. Madison, Wis.: Industrial Relations Research Association, pp. 3-45.

Cohen, Jacob, and Patricia Cohen. 1983. Applied Multivariate Regression/Correlation Analysis for the Behavioral Sciences. Hillsdale, N.J.: Lawrence Erlbaum Associates.

Cooley, William W., and Paul R. Lohnes. 1971. Multivariate Data Analysis. New York: Wiley.

Fiorito, Jack, D. G. Gallagher, and Cynthia V. Fukami. 1988. "Satisfaction with Union Representation." Industrial and Labor Relations Review, Vol. 41, No. 2 (January), pp. 294-307.

Fishbein, Martin, and Icek Ajzen. 1975. Belief, Attitude, Intention and Behavior: An Introduction to Theory and Research. Reading, Mass.: Addison Wesley.

Friedman, Lee, and Robert J. Harvey. 1986. "Factors of Union Commitment: The Case for a Lower Dimensionality." Journal of Applied Psychology, Vol. 71, No. 3 (August), pp. 371-76.

Fullagar, Clive, and Julian Barling. 1987. "Towards a
Model of Union Commitment." In D. Lipsky and D. Lewin, eds., Advances in Industrial and Labor Relations. Greenwich, Conn.: JAI Press, pp. 43-78. 1990. "A Longitudinal Test of a Model of the

Antecedents and Consequences of Union Loyalty." Journal of Applied Psychology, Vol. 74, No. 2 (April), pp. 213-27.

Gallagher, Daniel G., and Paul F. Clark. 1989. "Research on Union Commitment: Implications for Labor." Labor Studies Journal, Vol. 14, No. 1 (Spring), pp. 52-71.

Gallagher, Daniel G., and George Strauss. 1991. "Union Membership Attitudes and Participation." In George Strauss, Daniel G. Gallagher, and Jack Fiorito, eds., The State of the Unions. Madison, Wis: Industrial Relations Research Association, pp. 139-75

Gordon, Michael E., J. W. Philpot, R. E. Burt, C. A. Thompson, and W. E. Spiller. 1980. "Commitment to the Union: Development of a Measure and an Examination of Its Correlates." Journal of Applied Psychology, Vol. 65, No. 4 (August), pp. 479-99.

James, L. R., S. A. Mulaik, and J. M. Brett. 1982. Causal Analysis. Beverly Hills, Calif.: Sage.

Jarley, Paul, Sarosh Kuruvilla, and Douglas Casteel. 1990. "Member-Union Relations and Union Satisfaction." Industrial Relations, Vol. 29, No. 1 (Winter), pp. 128-34.

Jöreskog, K. B., and D. Sorbom. 1988. LISREL VII: Analysis of Linear Structural Relationships by the Method of Maximum Likelihood. Morrisville, Ind. Scientific Software.

Klandermans, Bert. 1989. "Union Commitment: Replications and Testing in a Dutch Context." Journal of Applied Psychology, Vol. 74, No. 6 (December), pp. 869-75.

Kochan, Thomas, A. 1979. "How American Workers View Labor Unions." Monthly Labor Review, Vol. 102, No. 4 (April), pp. 23-31.

Kuruvilla, Sarosh. 1989. "Union Attitudes: Three Essays on Dimensionality, Discriminant Validity and Union Attitude Formation." Ph.D. diss., University of lowa.

LO (Landsorganizationen). 1990a. "Även Kvinnorna Minskar i Facket." LO-Tidningen, No. 33, August 17.

1990b. "Gott om Arbete: Då Sviks Facket." LO-Tidningen, No. 35, August 31.

Locke, Edwin A. 1976. "The Nature and Causes of Job Satisfaction." In Marvin D. Dunnette, ed., Handbook of Industrial and Organizational Psychology. Chicago: Rand McNally, pp. 1297-1349.

Magenau, John M., James E. Martin, and Melanie M. Peterson. 1988. "Dual and Unilateral Commitment Among Stewards and Rank and File Union Members." Academy of Management Journal, Vol. 31, No. 2 (June), pp. 359-76.

McShane, Steven L. 1986. "A Path-Analytic Study of Participation in Union Administration." Industrial Relations, Vol. 25, No. 1 (Winter), pp. 72-80.

Montgomery, Ruth. 1989. "The Influence of Attitudes and Normative Pressures on Voting Deci- 
sions in a Union Representative Election." Industrial and Labor Relations Review, Vol. 42, No. 2 (January), pp. 262-79.

Mowday, Richard T., Lyman M. Porter, and Richard M. Steers. 1982. Employee-Organization Linkages: The Psychology of Commitment, Absenteeism and Turnover. New York: Academic Press.

Nicholson, Nigel, Gill Ursell, and Paul A. Blyton. 1981. The Dynamics of White Collar Unionism. London: Academic Press.

Pontusson, Jonas, and Sarosh Kuruvilla. 1992. "Swedish Wage-Earner Funds: An Experiment in
Economic Democracy." Industrial and Labor Relations Review, Vol. 45, No. 4 (July), pp. 779-91.

Salancik, Gerald R. 1977. "Commitment and Control of Organizational Behavior and Belief." In B. M. Staw and G. R. Salancik, eds., New Directions in Organizational Behavior. Chicago: St. Clair Press.

Strauss, George, and Gina Gargano. 1987. "Union Member Attitude Surveys: Content and Methodological Issues." Proceedings of the Fortieth Annual Meetings of the Industrial Relations Research Association. Madison.: Wisc.: IRRA, Pp. 159-62. 